\title{
The Influence of the Occupational Exposure to Heavy Metals and Tobacco Smoke on the Selected Oxidative Stress Markers in Smelters
}

\author{
Milena Ściskalska • Marta Zalewska • \\ Agnieszka Grzelak • Halina Milnerowicz
}

Received: 13 February 2014 / Accepted: 14 April 2014 / Published online: 1 May 2014

(C) The Author(s) 2014. This article is published with open access at Springerlink.com

\begin{abstract}
The aim of the study was to verify if there is any association between exposure to $\mathrm{Cu}, \mathrm{Zn}, \mathrm{Cd}, \mathrm{Pb}, \mathrm{As}$ and the formation of malondialdehyde (MDA), 8hydroxydeoxyguanosine $(8-\mathrm{OHdG})$, advanced oxidation protein products (AOPP), and whether in this process cigarette smoking plays a role. The investigations were performed in the 352 smelters occupationally exposed to heavy metals and 73 persons of control group. Metals concentration was determined by atomic absorption spectrometry. MDA and AOPP concentrations were determined by spectrophotometric methods. The concentration of $8-\mathrm{OHdG}$ was determined by ELISA method. It was demonstrated an increased $\mathrm{Cu}$ concentration in smoking smelters compared to non-smoking control group. It was noted no differences in $\mathrm{Zn}$ and $\mathrm{Mg}$ concentrations between the examined groups. $\mathrm{Pb}$ concentration was more than sixfold higher in the group of smoking smelters and about fivefold higher in the group of non-smoking smelters compared to the control groups (smokers and non-smokers). It was shown that $\mathrm{Cd}$ concentration in the blood was nearly fivefold higher in the smoking control group compared to the non-smoking control group and more than threefold higher in the group of smoking smelters compared to non-smoking. It was shown an increased As concentration (more than fourfold) and decreased $\mathrm{Ca}$ concentration in both groups
\end{abstract}

M. Ściskalska $\cdot$ M. Zalewska $(\triangle) \cdot$ H. Milnerowicz

Department of Biomedical and Environmental Analysis, Faculty of

Pharmacy, Wroclaw Medical University, Borowska 211,

50-556 Wrocław, Poland

e-mail: zalewska.m@gmail.com

A. Grzelak

Students Scientific Society at the Department of Biomedical Environmental Analysis, Faculty of Pharmacy, Wroclaw Medical

University, Borowska 211, 50-556 Wrocław, Poland of smelters compared to control groups. In groups of smelters (smokers and non-smokers), twofold higher MDA and AOPP concentrations, and AOPP/albumin index compared to control groups (smokers and nonsmokers) were shown. Tobacco smoke is the major source of $\mathrm{Cd}$ in the blood of smelters. Occupational exposure causes accumulation of $\mathrm{Pb}$ in the blood. Occupational exposure to heavy metals causes raise of MDA concentration and causes greater increase in AOPP concentration than tobacco smoke.

Keywords AOPP · Cadmium $\cdot$ Heavy metals $\cdot$ MDA . Tobacco smoke $\cdot 8$-OHdG

\section{Introduction}

Free radicals are not only formed continuously during normal physiological processes, but also as a result of external factors, including exposure to tobacco smoke in the case of smokers or to heavy metals in the work environment. In tobacco smoke, free radicals are responsible for cell damage and apoptosis [1]. They can cause DNA fragmentation, oxidative damage of cellular membrane lipids and proteins, and the reduction of enzyme activity through its oxidation and nitration [1-3]. The most important radicals, which have a strong toxic effect, are oxygen free radicals - superoxide anion $\left(\mathrm{O}_{2}{ }^{-}\right)$, hydroxyl radical $\left({ }^{\circ} \mathrm{OH}^{-}\right)$, hydrogen peroxide $\left(\mathrm{H}_{2} \mathrm{O}_{2}\right)$, and nitrogen free radicals - peroxynitrites $\left(\mathrm{NO}_{2}{ }^{-}\right)$and nitrates $\left(\mathrm{NO}_{3}{ }^{-}\right)$[3]. Except to these radicals generated directly, tobacco smoke contains many substances, such as polycyclic aromatic hydrocarbons, heterocyclic substances, N-nitrosamines, aromatic amines, and aldehydes, which are probably the main causes of biomolecules damage $[4,5]$. Components of tobacco smoke are also metals, e.g., arsenic, beryllium, nickel, chromium, cadmium, polonium, cobalt, and lead [4]. These 
substances have the ability to generate free radicals or catalyze reactions in which they are produced [3].

Oxidative stress can intensify lipids peroxidation. One of the most common products of lipid peroxidation is malonylodialdehyde (MDA), which is also generated in the process of biosynthesis of prostaglandins. MDA can be transmitted to distant tissues and, thanks to the possibility of forming covalent bonds with other molecules, modifies their structure, and consequently, changes its properties. MDA has high cytotoxicity, is mutagenic, and inhibits the activity of various enzymes, leading to inhibition of DNA replication, transcription, and breathing $[6,7]$. MDA is considered as a marker of oxidative damage of cell membrane. It is formed from the decomposition of primary and secondary lipids peroxidation products $[8,9]$. Another component of the cell which is characterized by its particular susceptibility to oxidative damage is DNA [7]. Free radicals can react with both purine and pyrimidine bases, as well as the deoxyribose. Oxidative stress can damage DNA comprising: breaking single or double strand, base modifications, deoxyribose modifications, and crosslinks formation. When DNA damage is not repaired before or during replication, this can lead to cell death, mutations, replication errors, and instability of the genome, each of which is associated with the process of carcinogenesis [6]. Of all the DNA nitrogen bases, guanine is the most susceptible to oxidation [10,11]. Hydroxyl radical addition to the eighth position of the molecule leads to the formation of guanine modified product-8 hydroxydeoxyguanosine $(8-\mathrm{OHdG})[11,12]$. Mutagenic character of 8-OHdG located in the DNA template is due to its potential for incorrect base pairing during replication. 8OHdG is capable of transversion G:C $\rightarrow \mathrm{T}$ :A. It has been shown that such transversions are common in human cancers and are especially prevalent in the p53 tumor suppressor gene. This indicates the importance of $8-\mathrm{OHdG}$ as an endogenous mutagen and its potential role in tumorigenesis [13].

Exposure of proteins to reactive oxygen species results in modification of amino acid residues, what alters protein structure and function [5]. The changes in proteins, which are induced by exposure to tobacco smoke, such as an increase of carbonyl groups content in the protein molecule were shown $[3,14]$. The protein oxidation can be caused also by the exposure on heavy metals, which are present in living or/ and occupational environment. The broad spectrum of heavy metals toxicity, such as $\mathrm{Pb}, \mathrm{Cd}$, and As, resulting from their ability to selective interaction with the fragments of protein chain, may induce the production of oxygen free radicals [15]. This toxicity of heavy metals can be reduced by the presence of $\mathrm{Ca}$ and $\mathrm{Mg}$ - an important macronutrients, which limit the absorption of metals, such as $\mathrm{Cd}$ and $\mathrm{Pb}$, in human and animals organisms $[16,17]$.

Albumin is a major protein of blood plasma, where it constitutes about $55 \%$ of all proteins. This protein is also a major and predominant antioxidant in plasma [18]. The ability of the albumin to perform these functions has a relationship with its structure, which may be destroyed by oxidative stress. Free radicals can interact with each other or with amino acids/ proteins. The modifications of amino acids lead to an increase of carbonyl groups and disulphides in the protein molecule, and reduce the number of $\alpha$-helices, what results in conformational changes of proteins $[3,19,20]$. The influence on the albumin function, in particular on its ability to transport, have not only free radicals, but also heavy metal ions. Their binding to albumin is in competition with other physiological substances transported by albumin. Toxic metals, as compounds with high affinity to the hydrophobic sites of albumin, cause a conformational change of the protein molecule, the amino acids oxidation, and the weakness of the ability to binding other ligands. In addition, the heavy metal ions present in the blood cause a chelation of physiological ligands. However, the strength of the phenomenon is dependent on the type of metal. In the presence of heavy metal ions, the toxins, which are transported by albumin, are displaced from the connections with protein. This results in an increase of free toxins in the blood, having an impact on the body [21, 22].

The oxidation of proteins, including albumin, leads to the formation of permanent products, which vary in terms of structure, function, and physicochemical properties. These are known as an advanced oxidation protein products (AOPP) [23]. Although the exact structure of AOPP is not completely understood, it is known that they are mainly derivatives of oxidatively modified albumin, its aggregates and/or fragments, but also fibrinogen and lipoproteins, glycoproteins, and globulins (e.g., thyroglobulin and $\gamma$-globulins) [18, 23-26].

The aim of the study was to verify if there is any association between exposure to metals $(\mathrm{Cu}, \mathrm{Zn}, \mathrm{Cd}, \mathrm{Pb}$, and $\mathrm{As}$ ) occurring in the work environment of smelters and the formation of MDA, 8-OHdG, and AOPP and whether in this process cigarette smoking plays a role. The influence of the exposure to heavy metals and tobacco smoke on the concentration of $\mathrm{Ca}$ and $\mathrm{Mg}$ also was analyzed.

\section{Material and Methods}

\section{Materials}

The investigations were performed in the whole blood, serum, plasma, and urine of 352 males working in the copper foundry and 73 healthy men, non-exposed occupationally to heavy metals, who were qualified as control group by clinician of primary medical care. The study protocol was approved by Local Bioethics Committee of Wroclaw Medical University (Nr KB: 469/2008). The study population was in similar age and similar BMI. Table 1 presents data concerning age, BMI, 
Table 1 Characteristics of the persons in control group and the group of smelters

\begin{tabular}{lll}
\hline & Smoking $X \pm \mathrm{SD}$ & Non-smoking $\mathrm{X} \pm \mathrm{SD}$ \\
\hline Control group & $(n=14)$ & $(n=59)$ \\
Age & $34.38 \pm 7.90$ & $36.64 \pm 11.49$ \\
BMI $\left[\mathrm{kg} / \mathrm{m}^{2}\right]$ & $26.98 \pm 5.48$ & $25.75 \pm 3.50$ \\
Years of work in smelter & - & - \\
Serum cotinine $[\mathrm{ng} / \mathrm{ml}]$ & $66.46 \pm 12.18^{\text {a }}$ & $3.46 \pm 3.47$ \\
Smelters & $(n=258)$ & $(n=94)$ \\
Age & $42.06 \pm 9.06$ & $44.02 \pm 8.86$ \\
BMI $\left[\mathrm{kg} / \mathrm{m}^{2}\right]$ & $26.02 \pm 3.66$ & $27.41 \pm 3.61$ \\
Years of work in smelter & $18.98 \pm 1.87$ & $19.99 \pm 8.82$ \\
Serum cotinine $[\mathrm{ng} / \mathrm{ml}]$ & $71.19 \pm 12.65^{\mathrm{a}}$ & $2.81 \pm 1.94$ \\
\hline
\end{tabular}

${ }^{a} p<0.0001$ compared to non-smoking group

$B M I$ body mass index

years of work in metallurgy, and cotinine concentration in serum of smelters and persons of control group divided into smokers (22 pack years of smoking) and non-smokers: 258 smoking smelters, 94 non-smoking smelters, 14 smokers of control group, and 59 non-smokers of control group. Data about smoking were obtained from direct personal interview and were verified by the determination of serum cotinine concentration - the metabolite of nicotine.

Venous blood was collected in the morning, after 12-h fasting. Serum was obtained according to the standard procedure by taking venous blood for disposable trace element-free tubes (No. Cat 03.1524.001, Sarstedt, Germany) with serum clotting activator, left at $25{ }^{\circ} \mathrm{C}$ to complete thrombosis, and centrifuged $(1,200 \mathrm{~g} / 20 \mathrm{~min})$. In order to obtain plasma, blood was collected into trace element-free tubes containing EDTA$\mathrm{K}_{2}$ (No. Cat 04.1931.001, Sarstedt, Germany), immediately gently mixed, and centrifuged $(2,500 \mathrm{~g} / 15 \mathrm{~min})$. The obtained serum, plasma, and whole blood were portioned and stored in sealed tubes (No. Cat. 0030102.002, Eppendorf, Germany). Blood samples of smelters and persons of control groups were stored at $-80^{\circ} \mathrm{C}$ until analysis.

The urine was collected in the morning, according to the standard procedure. Subjects were asked to wash their hands before supplying the urine, in order to reduce contamination. Urine samples were stored in special container containing liquid nitric acid at $-20^{\circ} \mathrm{C}$ until determination.

\section{Metals Concentration}

Concentrations of metals were determined using Solaar M6 aparatus (Solaar House, Cambridge, UK). The Pb concentration in whole blood $(\mathrm{Pb}-\mathrm{B})$ was determined by graphite furnace atomic absorption spectrometry (GFAAS) in the graphite Massman cuvette, the absorbance measurement at wavelength $\lambda=283.3 \mathrm{~nm}$, with Zieeman background correction. The reference material was used BCR-194, -195, -196, IRMM, EU. The Cd concentration in whole blood (Cd-B) and in urine (Cd-U) was determined by the same method at wavelength $\lambda=$ $228.8 \mathrm{~nm}$, with Zieeman background correction. The concentration of $\mathrm{Zn}$ and $\mathrm{Cu}$ in serum $(\mathrm{Zn}-\mathrm{S}$ and $\mathrm{Cu}-\mathrm{S})$ was determined by flame atomic absorption spectrometry (FAAS) in air-acetylene flame at wavelength $\lambda=324.8 \mathrm{~nm}$. The reference material was used Single-Element Zinc (Copper), standard $1000 \mu \mathrm{g} / \mathrm{ml}$, CPI International. The determination of $\mathrm{Ca}$ and $\mathrm{Mg}$ concentrations in serum ( $\mathrm{Ca}-\mathrm{S}$ and $\mathrm{Mg}-\mathrm{S})$ was also performed by this method at wavelength $\lambda=422.7 \mathrm{~nm}$ for $\mathrm{Ca}$ and $\lambda=285.2 \mathrm{~nm}$ for $\mathrm{Mg}$, with deuterium correction of the glass. As a reference material for these metals was used Seronorm ${ }^{\mathrm{TM}}$ Trace Element Serum (Sero, No. 201 405). The As concentration in urine (As-U) (with $65 \% \mathrm{HNO}_{3}$ for acidification) was determined by FAAS method with snap Phillips PU 9360, used for hydride generation. In this method, wavelength $\lambda=$ $193.7 \mathrm{~nm}$ deuterium background correction and quartz atomization chamber were used.

\section{Creatinine Concentration in Urine}

Urinary creatinine level was determined by the Jaffé reaction [27].

\section{Cotinine Concentration}

Serum cotinine concentration was determined using a competitive enzyme immunoassay, the DRG Serum Cotinine ELISA kit (Cat. No. EIA-3242, DRG International, USA). The cotinine determination was carried out by the method described earlier [28, 29].

\section{Plasma MDA Concentration (MDA-P)}

Lipid peroxidation was measured in plasma by measuring the formation of thiobarbituric acid reactive substances (TBARS), quantified as malondialdehyde (MDA) equivalents, according to the method described earlier [30,31]. The amount of MDA was calculated using an extinction coefficient $(1.56 \times$ $10^{5} \mathrm{M}^{-1} \mathrm{~cm}^{-1}$ ). The MDA intensity was measured by spectrophotometric method at $\lambda=535 \mathrm{~nm}$. The concentrations of MDA were expressed as micromoles per liter in plasma.

\section{Serum 8-OHdG Concentration (8-OHdG-S)}

To evaluate the concentration of $8-\mathrm{OHdG}$ in the serum, a commercial test OxiSelect ${ }^{\mathrm{TM}}$ DNA Oxidative Damage ELISA Kit was used (Cat. No. STA-320, Cell Biolabs, Inc., USA). To 96-well plate, $100 \mu \mathrm{l}$ of conjugate 8-OHdG/BSA was added and incubated overnight at $4{ }^{\circ} \mathrm{C}$, and then washed with $\mathrm{H}_{2} \mathrm{O}$. The next step, $200 \mu$ l blocking buffer was added and incubated at room temperature for $1 \mathrm{~h}$. Fifty microliter of samples and 
8-OHdG standards were added. After 10 min of incubation, monoclonal anti-8-OHdG was added $(100 \mu \mathrm{l}, 1 \mathrm{~h}$ incubation at room temperature), washed three times followed by addition of secondary antibody conjugated to horseradish peroxidase $(100 \mu \mathrm{l}, 1 \mathrm{~h}$ incubation at room temperature). The plate was washed three times with washing buffer and to each well $100 \mu \mathrm{l}$ of substrate for peroxidase was added and incubated for $20 \mathrm{~min}$. Followed by the addition of $100 \mu \mathrm{l}$ of reaction stop solution. A spectrophotometric measurement of absorbance was performed at a wavelength $\lambda=450 \mathrm{~nm}$. The content of 8$\mathrm{OHdG}$ in the tested samples was calculated by comparison with a standard curve determined from standards treated similarly to the samples tested.

\section{Plasma AOPP Concentration (AOPP-P)}

Determination of AOPP-P concentration was performed by spectrophotometric method developed by Witko-Sarsat et al. [26], based on the reaction of AOPP with potassium iodide in acidic conditions. To $1 \mathrm{ml}$ of plasma, tenfold diluted with

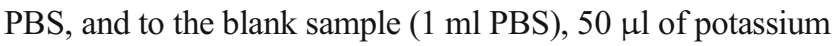
iodide (99 \%) and $100 \mu$ l of acetic acid $(99.5 \%)$ were added and mixed. The absorbance of samples was measured against the blank at wavelength $\lambda=340 \mathrm{~nm}$. The results of determination were expressed in micromoles per liter chloramine $\mathrm{T}$ equivalents and also were converted per gram of albumin and expressed as AOPP/albumin index ( $\mu \mathrm{mol} / \mathrm{g})$.

\section{Serum Albumin Concentration (Alb-S)}

Alb-S concentration was determined by using the bromocresol purple (BCP) (Cat. No. 115-40-2, SigmaAldrich), which reacts with albumin in phosphate buffer saline (PBS) at $\mathrm{pH}=6.8$. The concentration of albumin standard (Cat. No. 70024-90-70, Sigma-Aldrich) was determined using the molar absorption coefficient $\left(\mathrm{A}_{280 \mathrm{~nm}} \mathrm{~nm}^{0.1 \%}=0.5\right)$. To make the standard curve, the standard solutions at concentrations $0,11.3,22.6,33.9,45.2,56.5 \mathrm{~g} / 1$ were prepared, which were obtained by the dilution of albumin in PBS.

For each of the tubes, working reagent (with the final concentration of BCP $40 \mu \mathrm{mol} / \mathrm{l}$ ), serum sample, or albumin standard were added and mixed. All samples were incubated for $5 \mathrm{~min}$ at $25^{\circ} \mathrm{C}$. Absorbances of the standards and of the samples were measured against the blank sample (working reagent) at wavelength $\lambda=603 \mathrm{~nm}$. The increase in absorbance was proportional to the concentration of albumin in the sample.

\section{Statistical Analysis}

Statistical analysis was carried out using the program Statistica 10.0. Data about examined groups, BMI, age, years of work in smeltery, and cotinine concentration, were analysed using ANOVA Kruskal-Wallis test. The concentration of metals (Cu-S, Zn-S, Pb-B, Cd-B, Cd-U, As-U, Ca-S, and Mg-S), MDA-P, 8-OHdG, AOPP-P, albumin, and the value of AOPP/albumin index also using the same test were analyzed. In order to verify the association between parameters (age, BMI, concentration of cotinine, metals, MDA-P, AOPP$\mathrm{P}$, albumin, and $\mathrm{AOPP} / \mathrm{albumin}$ index), the multiple linear regression models were performed. Statistical significance was accepted for $p<0.05$.

\section{Results}

The Concentrations of Metals

In this study, the concentrations of $\mathrm{Cu}, \mathrm{Zn}, \mathrm{Ca}$, and $\mathrm{Mg}$ in serum; $\mathrm{Pb}$ and $\mathrm{Cd}$ in whole blood; and $\mathrm{Cd}$ and $\mathrm{As}$ in urine were determined (Table 2). In the smoking smelters, a higher concentration of $\mathrm{Cu}$ in serum $(\mathrm{Cu}-\mathrm{S})$ compared to nonsmoking control group was shown. There was no statistically significant difference in serum $\mathrm{Zn}(\mathrm{Zn}-\mathrm{S})$ and $\mathrm{Mg}(\mathrm{Mg}-\mathrm{S})$ concentrations between smoking and non-smoking smelters, and between smoking and non-smoking control group. In the serum of smoking and non-smoking smelters, the decrease of $\mathrm{Ca}$ concentration $(\mathrm{Ca}-\mathrm{S})$ in comparison to the smokers and non-smokers in control group was noted.

In both smoking and non-smoking smelters, a significant increase in the concentration of $\mathrm{Pb}$ in the blood $(\mathrm{Pb}-\mathrm{B})$ compared to the control group (smokers and non-smokers) was observed. In the group of smoking smelters, 6-fold increase in $\mathrm{Pb}-\mathrm{B}$ concentration in comparison to the smoking control group and 7.4-fold higher in relation to the non-smoking control group were observed. In the group of the nonsmoking smelters, 5.7-fold higher Pb-B concentration compared to the non-smoking control group was observed. The concentration of $\mathrm{Cd}$ in the blood (Cd-B) was significantly higher at smokers (both the smelters and the control group) compared to non-smokers. In the blood of smokers (both the smelters and the control group), 3.3-fold higher Cd concentration compared to the non-smoking smelters and 4.8 -fold higher compared to the non-smoking control group were observed.

In the group of smoking smelters, 2.5-fold higher concentration of $\mathrm{Cd}$ in urine (Cd-U) compared to the non-smoking control group was observed. In the urine of smoking and non-smoking smelters, As concentration (As-U) was significantly higher compared to control groups (both smokers and non-smokers). In the smelters (smoking and non-smoking), more than 4-fold higher of As-U concentration in comparison to the smoking control group and more than 4.6-fold higher compared to the non-smoking control group were observed. 
Table 2 Influence of cigarette smoking on the metals concentrations in the group of smelters and control group

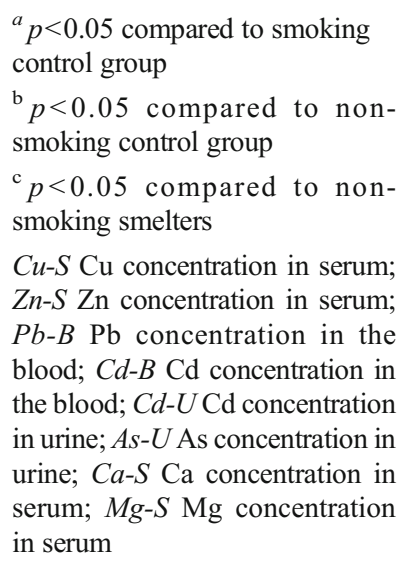

\begin{tabular}{|c|c|c|c|c|}
\hline \multirow[t]{2}{*}{ Metal } & \multicolumn{2}{|l|}{ Smelters } & \multicolumn{2}{|l|}{ Control group } \\
\hline & $\begin{array}{l}\text { Smoking } \\
(n=258) \\
X \pm \mathrm{SD}\end{array}$ & $\begin{array}{l}\text { Non-smoking }(n=94) \\
\mathrm{X} \pm \mathrm{SD}\end{array}$ & $\begin{array}{l}\text { Smoking } \\
(n=14) \\
\mathrm{X} \pm \mathrm{SD}\end{array}$ & $\begin{array}{l}\text { Non-smoking } \\
(n=59) \\
\mathrm{X} \pm \mathrm{SD}\end{array}$ \\
\hline $\begin{array}{l}\mathrm{Cu}-\mathrm{S} \\
{[\mu \mathrm{g} / 100 \mathrm{ml}]}\end{array}$ & $107.22 \pm 13.22^{\mathrm{b}}$ & $104.00 \pm 13.63$ & $102.29 \pm 13.46$ & $97.76 \pm 10.66$ \\
\hline $\mathrm{Zn}-\mathrm{S}$ & $101.22 \pm 23.37$ & $97.60 \pm 18.44$ & $99.22 \pm 10.67$ & $96.97 \pm 9.22$ \\
\hline $\begin{array}{l}\mathrm{Pb}-\mathrm{B} \\
{[\mu \mathrm{g} / \mathrm{l}]}\end{array}$ & $229.91 \pm 127.75^{\mathrm{a}, \mathrm{b}}$ & $177.91 \pm 125.17^{\mathrm{a}, \mathrm{b}}$ & $37.95 \pm 14.15$ & $31.01 \pm 7.91$ \\
\hline Cd-B & $1.52 \pm 0.98^{\mathrm{b}, \mathrm{c}}$ & $0.46 \pm 0.33^{\mathrm{a}}$ & $1.52 \pm 0.77^{\mathrm{b}}$ & $0.32 \pm 0.10$ \\
\hline Cd-U [ $\mu \mathrm{g} / \mathrm{g}$ creatinine $]$ & $0.83 \pm 0.66^{\mathrm{a}, \mathrm{b}}$ & $0.56 \pm 0.41$ & $0.44 \pm 0.26$ & $0.32 \pm 0.20$ \\
\hline $\begin{array}{l}\text { As-U } \\
{[\mu \mathrm{g} / \mathrm{g} \text { creatinine }]}\end{array}$ & $12.76 \pm 7.69^{\mathrm{a}, \mathrm{b}}$ & $13.01 \pm 9.56^{\mathrm{a}, \mathrm{b}}$ & $3.14 \pm 2.16$ & $2.73 \pm 1.24$ \\
\hline $\begin{array}{l}\mathrm{Ca}-\mathrm{S} \\
{[\mu \mathrm{g} / \mathrm{ml}]}\end{array}$ & $89.81 \pm 8.03^{\mathrm{a}, \mathrm{b}}$ & $90.77 \pm 8.34^{\mathrm{a}, \mathrm{b}}$ & $97.59 \pm 4.64$ & $100.02 \pm 4.02$ \\
\hline $\begin{array}{l}\mathrm{Mg}-\mathrm{S} \\
{[\mu \mathrm{g} / \mathrm{ml}]}\end{array}$ & $21.08 \pm 2.01$ & $20.62 \pm 1.10$ & $19.76 \pm 1.64$ & $20.70 \pm 1.70$ \\
\hline
\end{tabular}

MDA-P, 8-OHdG-S, and AOPP-P Concentrations as Markers of Lipids Peroxidation, Oxidatively Modified DNA, and Protein Oxidation

In the groups of smelters (smokers and non-smokers), 2-fold higher MDA-P concentration compared to control groups (respectively, smokers and non-smokers) was shown (Table 3). However, there was no statistically significant difference in $8-O H d G-S$ concentration between smoking and non-smoking smelters, and between smoking and non-smoking control group (Table 3).

In the plasma of smoking and non-smoking smelters, 2fold higher of AOPP-P concentration in comparison to the smoking control group and 2.2-fold higher compared to the non-smoking control group was shown (Table 3). There were no statistically significant differences in Alb-S concentration between smoking and non-smoking smelters, and between smoking and non-smoking control group (Table 3).

AOPP/albumin index, which is expressed in micromole as the amount of AOPP per gram of albumin, was calculated. In the group of smoking smelters, 1.7-fold increase in the value AOPP/albumin index compared to the smoking control group and 3-fold increase of this parameter compared to the nonsmoking control group was observed. 2.3-fold increase in the value of AOPP/albumin index in the non-smoking smelters compared to non-smoking control group was observed (Table 3).

\section{Correlations}

In the serum of non-smoking smelters, the correlation was demonstrated between the concentration of $\mathrm{Cu}-\mathrm{S}$ and $\mathrm{Alb}-\mathrm{S}$
( $r=-0.4646, p=0.0103)$. The correlation of $\mathrm{Pb}-\mathrm{B}$ and AOPP$\mathrm{P}$ concentrations $(r=0.5219, p=0.0073)$, and the AOPP/albumin index $(r=0.3689, p=0.0369)$ in this group also were shown.

\section{Discussion}

Tobacco smoke and environmental or occupational exposure to heavy metals can cause many health effects in organism of copper foundry workers. Depending on intensity and duration of the exposure, they can change the biological functions of organs, such as liver and kidney. Lead, arsenic, and cadmium belong to toxic agents, which can disturb function of cardiovascular system. Heavy metals can produce free radicals, which leads to pro-oxidant/antioxidant imbalance and oxidative stress. It leads to the disturbances of cellular metabolism resulting in the formation of permanent changes caused by the oxidation in the structure of lipids, proteins, and DNA [32]. The oxidation products are MDA, AOPP and 8-OHdG respectively. The association of the MDA, 8-OHdG, and AOPP formation and oxidative stress was confirmed in subsequent studies [2, 18, 26, 33-38].

It was demonstrated that occupational exposure causes an increase in serum $\mathrm{Cu}$ concentration in smelters (104.5士 $15.1 \mu \mathrm{g} \%)$ compared to controls (99.7 $\pm 12.1 \mu \mathrm{g} \%$ ) [39]. Also, in our study, the highest $\mathrm{Cu}-\mathrm{S}$ concentration in the group of smoking smelters was shown. This indicates that $\mathrm{Cu}-\mathrm{S}$ concentration was increased with the number of oxidizing factors, especially during exposure to heavy metals. It confirmed that $\mathrm{Cu}$ can be replaced through heavy metals in 
Table 3 Influence of cigarette smoking on MDA, 8-OHdG, AOPP, albumin concentrations, and AOPP/albumin index in the group of smelters and control group

\begin{tabular}{|c|c|c|c|c|}
\hline \multirow[t]{2}{*}{ Parametr } & \multicolumn{2}{|l|}{ Smelters } & \multicolumn{2}{|l|}{ Control group } \\
\hline & $\begin{array}{l}\text { Smoking } \\
(n=258) \\
X \pm \operatorname{SD}\end{array}$ & $\begin{array}{l}\text { Non-smoking }(n=94) \\
\mathrm{X} \pm \mathrm{SD}\end{array}$ & $\begin{array}{l}\text { Smoking } \\
(n=14) \\
\mathrm{X} \pm \mathrm{SD}\end{array}$ & $\begin{array}{l}\text { Non-smoking } \\
(n=59) \\
\mathrm{X} \pm \mathrm{SD}\end{array}$ \\
\hline $\begin{array}{l}\text { MDA-P } \\
{[\mu \mathrm{mol} / 1]}\end{array}$ & $1.56 \pm 0.76^{\mathrm{a}, \mathrm{b}}$ & $1.54 \pm 0.65^{\mathrm{a}, \mathrm{b}}$ & $0.74 \pm 0.12$ & $0.80 \pm 0.24$ \\
\hline $\begin{array}{l}\text { 8-OHdG-S } \\
{[\mathrm{ng} / \mathrm{ml}]}\end{array}$ & $2.73 \pm 0.31$ & $2.63 \pm 0.41$ & $2.60 \pm 0.48$ & $2.61 \pm 0.38$ \\
\hline $\begin{array}{l}\text { AOPP-P } \\
{[\mu \mathrm{mol} / 1]}\end{array}$ & $57.63 \pm 22.53^{\mathrm{a}, \mathrm{b}}$ & $59.46 \pm 21.98^{\mathrm{a}, \mathrm{b}}$ & $30.85 \pm 12.95$ & $25.93 \pm 10.31$ \\
\hline Alb-S [g/l] & $50.67 \pm 8.58$ & $52.52 \pm 8.89$ & $53.14 \pm 6.62$ & $51.00 \pm 8.07$ \\
\hline $\begin{array}{l}\text { AOPP/albumin index } \\
{[\mu \mathrm{mol} / \mathrm{g}]}\end{array}$ & $1.09 \pm 0.50^{\mathrm{a}, \mathrm{b}}$ & $1.14 \pm 0.46^{\mathrm{a}, \mathrm{b}}$ & $0.64 \pm 0.18^{\mathrm{b}}$ & $0.49 \pm 0.17$ \\
\hline \multicolumn{5}{|c|}{${ }^{\mathrm{a}} p<0.05$ compared to smoking control group } \\
\hline \multicolumn{5}{|c|}{${ }^{\mathrm{b}} p<0.05$ compared to non-smoking control group } \\
\hline \multicolumn{5}{|c|}{${ }^{\mathrm{c}} p<0.05$ compared to non-smoking smelters } \\
\hline
\end{tabular}

antioxidant enzymes, such as $\mathrm{Cu} / \mathrm{Zn}$ superoxide dismutase (EC 1.15.1.1), which can result in the inhibition of antioxidant enzymes activity and an increase in oxidative stress [40]. On the other hand, in our study, there was no difference in $\mathrm{Zn}-\mathrm{S}$ concentration in examined groups. It suggested the adaptation of healthy smelters to the environmental conditions, which was shown in others studies [41].

Bizon et al. (2013) demonstrated that exposure to heavy metals causes an increase of $\mathrm{Pb}-\mathrm{B}$ concentration [42]. Higher $\mathrm{Pb}-\mathrm{B}$ concentration in the group of persons exposed to heavy metals $(277.18 \pm 119.14 \mu \mathrm{g} / \mathrm{l})$ compared to the control group $(32.11 \pm 8.89 \mu \mathrm{g} / \mathrm{l})$ was shown [42]. In other studies, a significant increase in $\mathrm{Pb}-\mathrm{B}$ concentration in the group of smelters $(201.2 \pm 112.5 \mu \mathrm{g} / \mathrm{l})$ compared to the people not exposed to this metal $(37.9 \pm 27.1 \mu \mathrm{g} / \mathrm{l})$ was also shown [39]. In our study, a significant increase in $\mathrm{Pb}-\mathrm{B}$ concentration in the groups of smelters compared to the control groups was observed. In the smoking smelters, the concentration of $\mathrm{Pb}$ was nearly sixfold higher in comparison to the nonsmoking control group. It was also shown that $\mathrm{Pb}-\mathrm{B}$ concentration in the group of smelters almost twofold exceeded the permissible level of this metal in the blood $(<100 \mu \mathrm{g} / \mathrm{l})$ [39, 43]. The $\mathrm{Pb}-\mathrm{B}$ concentrations in the control groups were smaller than $100 \mu \mathrm{g} / \mathrm{l}$. This confirms that the high $\mathrm{Pb}-\mathrm{B}$ concentration was caused mainly by occupational exposure, and cigarette smoking was not the main source of $\mathrm{Pb}-\mathrm{B}$.

$\mathrm{Cd}-\mathrm{B}$ and $\mathrm{Cd}-\mathrm{U}$ concentrations increase during exposure to tobacco smoke, that was observed by other scientists. Bizoń et al. (2013) demonstrated an increase in Cd-B concentration of smokers compared to non-smokers, both in the control group and the group of smelters $(0.43 \pm 0.39 \mu \mathrm{g} / 1,1.59 \pm$ $0.79 \mu \mathrm{g} / 1$ and $1.69 \pm 0.70 \mu \mathrm{g} / \mathrm{l}$, respectively, for the nonsmoking control group and smoking control group $<20$ cigarettes/day and $>20$ cigarettes/day and $0.54 \pm 0.44 \mu \mathrm{g} / \mathrm{l}$, $2.19 \pm 1.51 \mu \mathrm{g} / \mathrm{l}$ and $3.05 \pm 2.29 \mu \mathrm{g} / \mathrm{l}$, respectively, for nonsmoking and smoking smelters $<20$ cigarettes/day and $>20$ cigarettes/day) [42]. In other studies, the difference between Cd-B concentration in smokers $(1.3 \mu \mathrm{g} / \mathrm{l})$ and non-smokers $(0.4 \mu \mathrm{g} / \mathrm{l})$ was shown [44]. Madeddu et al. (2011) also demonstrated that cigarette smoking causes an increase of the $\mathrm{Cd}$ B concentration $(0.46$ and $0.29 \mu \mathrm{g} / \mathrm{l}$, respectively, for smokers and non-smokers) [45]. In this study, nearly fivefold higher of $\mathrm{Cd}-\mathrm{B}$ concentration in the group of smokers compared to nonsmokers (both smelters and the control group) was shown. Cd-B concentration in the group of smokers (both smelters and the control group) exceeded about threefold the value of permissible level $(<0.5 \mu \mathrm{g} / \mathrm{l})[39,43]$. In the group of nonsmokers (both smelters and the control group), it did not exceed the permissible value. This emphasizes the importance of the influence of cigarette smoking on Cd-B concentration. It was observed higher $\mathrm{Cd}-\mathrm{U}$ concentration in the smoking groups compared to non-smoking groups (both smelters and the control group). It was noted a higher $\mathrm{Cd}-\mathrm{U}$ concentration in the group of smoking smelters compared to the smoking control group. It can suggest that occupational exposure to heavy metals accompanying exposure to tobacco smoke raised $\mathrm{Cd}-\mathrm{U}$ concentration. This data confirmed that the main factor influencing on the $\mathrm{Cd}-\mathrm{B}$ and $\mathrm{Cd}-\mathrm{U}$ concentration is cigarette smoking. Occupational exposure to this metal seems 
to have lower importance on its concentration in the human body than cigarette smoking.

An increase of As-U concentration in the group of persons occupationally exposed to heavy metals $(18.9 \pm 22.2 \mu \mathrm{g} / \mathrm{g}$ creatinine $)$ in comparison to the control group $(3.5 \pm 3.0 \mu \mathrm{g} / \mathrm{g}$ creatinine) was observed [39]. Bizoń et al. (2013) also have shown higher As-U concentration in smelters compared to the control group [42]. Our study confirmed the influence of occupational exposure on As-U, because in the groups of smelters (smokers and non-smokers) more than fourfold an increase in As-U concentration compared to the control groups was shown. It was also observed that in the group of smelters, As-U concentration exceeded the value of permissible level $(<10 \mu \mathrm{g} / \mathrm{g}$ creatinine) [39].

The concentrations of $\mathrm{Ca}$ and $\mathrm{Mg}$ macroelements, which values have a significant impact on the reduction of the penetration capability of some toxic metals, such as $\mathrm{Cd}$ and $\mathrm{Pb}$ were also determined. The demonstrated differences in $\mathrm{Ca}-$ $\mathrm{S}$ concentration between the groups of smelters and control groups (both smokers and non-smokers) confirm that exposure to heavy metals causes a decrease Ca-S concentration. These results are similar to the study made by Kossowska et al., where was demonstrated a difference between $\mathrm{Ca}-\mathrm{S}$ concentration in the group of smelters $(90.4 \pm 7.3 \mu \mathrm{g} / \mathrm{ml})$ and the control group $(99.3 \pm 4.1 \mu \mathrm{g} / \mathrm{ml})$ [39]. In our study, the influence of occupational exposure and cigarette smoking on $\mathrm{Mg}-\mathrm{S}$ concentration was not observed. It is known that $\mathrm{Mg}$ has antioxidant properties, scavenging oxygen radicals, possibly by affecting the rate of spontaneous dismutation of the superoxide ion [46]. It was shown that $\mathrm{Mg}$ can inhibit lipoprotein oxidation and enhances the antioxidant enzymes activity, which reduces oxidative stress [47]. In our study, this effect was not observed. There was no difference in Mg-S concentration between examined groups. It can suggest that lipids peroxidation and protein oxidation in smelters were not mediated thought reduced level of $\mathrm{Mg}$-S or its deficiency.

Chronic exposure to heavy metals causes their accumulation in tissues and has the influence on the human health [48-50]. It was observed an increase in the concentration of $\mathrm{Pb}-\mathrm{B}, \mathrm{Cu}-\mathrm{S}$, and As-U in the group of smelters, which confirms that the occupational exposure is the source of these metals. However, Cd-B concentration increases during exposure to tobacco smoke. Both occupational exposure to heavy metals and tobacco smoke intensify the oxidative stress. It results in the lipids peroxidation expressed as MDA production and/or protein oxidation and the formation of AOPP.

There was observed significantly higher plasma MDA levels $(2.67 \pm 0.69 \mu \mathrm{M})$ of workers exposed to lead than those in the control group $(1.23 \pm 0.61 \mu \mathrm{M})$ [51]. However, the results presented by Dursun et al. indicate that increased concentrations of lipid peroxidation products in the blood of persons exposed to lead is dependent not only on the concentrations of lead, but also on the age and time of exposure [51].
Other researches have also shown that MDA concentrations were elevated in the all heavy metal-treated groups compared to the control groups [52]. In this study, MDA concentrations in the group of smelters (both smokers and non-smokers) were nearly 2-fold higher compared to smoking and non-smoking control groups, which confirms that oxidative stress is generated in the result of occupational exposure in the smeltery. Increased concentration of MDA confirms the relationship between occupational exposure to heavy metals and the development of oxidative stress, and its effect on cell membranes. An increase in lipids peroxidation in smelters is a major sign of oxidative stress in the blood, which can result in the changes of tissues and organs.

Barbato et al. (2010) conducted a meta-analysis in environmental pollution exposed employees and in five studied groups, increase of 8-OHdG in the urine was observed, and in three studied group, there was no effect [53]. Garçon et al. (2007) studied the effects of chronic exposure to cadmium and lead on kidney function, they have also not observed differences in the concentration of the marker in the urine between smelters and control group (respectively, $12.7 \pm 5.6$ and $12.4 \pm$ $5.9 \mu \mathrm{g} / \mathrm{g}$ creatinine) [54]. Wu et al. (2004) have not found any difference in the concentration of $8-\mathrm{OHdG}$ in urine among smokers and people not exposed to tobacco smoke [11]. Musarrat et al. (1996) also found that adducts of 8-OHdG concentration does not correlate with smoking [55]. This study has shown no significant difference in the level of 8-OHdG concentration in none of group. This indicates that both cigarette smoking and metals exposure appear to have only a small effect on 8-OHdG level in the blood.

It should be noted that AOPP concentration depends on many physiological and environmental factors, which may influence on the examined population (age, body weight, sex, environmental pollution, cigarette smoking, and physical condition) [56-59]. The impact of additional factors, except tested factors, is so large that wrong classification to the control group or not adequate comparison of obtained results with these from other studies can make the results uncomparable. This is confirmed by the fact of the lack of standardized method for the determination of AOPP, which was noticed by other researchers [18]. In this study, examined groups were standardized in terms of sex, age, BMI, and environmental exposure to heavy metals.

There are some studies demonstrating the impact of cigarette smoking on the formation the changes in the structure of proteins. It was shown an increase in the amount of carbonyl groups in the molecules of proteins, which are the component of AOPP. A difference in the amount of carbonyl groups was shown between the group of persons, which were intensive smokers $(4.00 \pm 1.31 \mathrm{nmol} / \mathrm{mg}$ protein) and the persons not exposed to tobacco smoke $(0.80 \pm 1.94 \mathrm{nmol} / \mathrm{mg}$ protein) [14]. However, others researchers found no differences in concentration of carbonyl groups between current and former 
smokers $(17.9 \pm 2.9 \mathrm{nmol} / \mathrm{ml}$ plasma for both groups) [5]. Also was shown no difference in the concentration of carbonyl groups between persons, which were a long-term smokers $(17.9 \pm 2.8$ and $17.9 \pm 3.1 \mathrm{nmol} / \mathrm{ml}$ plasma, respectively, for smokers 30 -45 years and $>45$ years), and the persons, which were smokers $<30$ years $(17.7 \pm 2.7 \mathrm{nmol} / \mathrm{ml}$ plasma) [5]. In some studies, it was shown that the tobacco smoking has no influence on the structure of proteins; in others, it was shown that it can induce protein oxidation measured as the increase in the amount of carbonyl groups in their molecules. This indicates that the influence of tobacco smoking on the changes in proteins structure and the formation of AOPP are not clearly defined. In our study, it was shown no influence of tobacco smoke on an increase of AOPP-P concentration. However, AOPP-P concentration was more than twofold higher in the groups of smelters than in the control groups. This indicates an influence of occupational exposure on protein oxidation. Occupational exposure to heavy metals causes a significant increase in AOPP-P concentration. Differences in this parameter resulting from the impact of tobacco smoke on protein oxidation were less visible than resulting from occupational exposure.

Because of the fact that in the composition of AOPP is mainly the products of albumin's oxidation; the determination of this protein in the serum of smelters was an important element of this study. On the concentration of AOPP, it has an influence not only in many factors discussed above, but also the concentration of albumin in the blood of the examined persons, which were in reference range (35-55 g/l) [60]. For this reason, the parameter better expressing the changes in AOPP concentration is its conversion per gram of albumin in the blood [61-62]. The expression of AOPP concentration as AOPP/albumin index in this study allowed to make the amount of AOPP independent from the inter-person variability in the concentration of albumin. This enables to better define an exposure to oxidation factors (heavy metals and tobacco smoke). In this study, the conversion of AOPP per gram of albumin permitted to detect a statistically significant difference in the AOPP-P concentration between smoking and non-smoking control group. This difference was not detected in the case of AOPP-P concentration expressed in micromoles per liter (using the same statistical test for both parameters). It was shown that the value of AOPP/albumin index increased with the exposure to factors causing the formation of AOPP (heavy metals and also tobacco smoke).

In this study, it was demonstrated that an important factor influencing AOPP-P concentration is occupational exposure to heavy metals, especially $\mathrm{Cu}$. The inverse correlation between $\mathrm{Cu}-\mathrm{S}$ and Alb-S concentration may indicate the participation of $\mathrm{Cu}$ in the formation of AOPP and its oxidation effect on albumin. In the group of non-smoking smelters, it was demonstrated the correlation between the concentration of $\mathrm{Pb}-\mathrm{B}$ and AOPP-P, and the value of AOPP/albumin index. This may indicate that high $\mathrm{Pb}-\mathrm{B}$ concentration is an oxidation factor for proteins. These results suggest that $\mathrm{Cu}$ and $\mathrm{Pb}$ play an important role in protein oxidation. $\mathrm{Cu}$ can generate free radicals by Fenton reaction. Additionally, $\mathrm{Pb}$ can replace $\mathrm{Cu}$ in antioxidant enzymes that causes an increase in serum $\mathrm{Cu}$ concentration and intensifies an oxidative stress.

In this study, it was confirmed the influence of heavy metals exposure on lipids peroxidation. It indicates that occupationally exposure can have an important role in lipid degradation and cell damage. It was not observed any effect of heavy metals exposure or cigarette smoking on oxidative modification of DNA. It was shown that cigarette smoking and occupational exposure to heavy metals have an influence on protein oxidation. These oxidizing factors of which the source is the environment seem to be important for destruction of protein molecule and limit its function.

\section{Conclusions}

In this study, it was confirmed that tobacco smoke is the main source of $\mathrm{Cd}$ in the blood of smelters. The occupational exposure on heavy metals has no influence on Cd-B and Cd-U concentrations. With the increasing exposure to tobacco smoke and heavy metals, $\mathrm{Ca}$ concentration in serum was decreased.

Exposure to heavy metals causes an increase of heavy metals concentrations in the blood, especially $\mathrm{Pb}-\mathrm{B}$, but also $\mathrm{Cu}-\mathrm{S}$ and $\mathrm{As}-\mathrm{U}$ of smelters. This oxidizing factor intensifies lipids peroxidation and causes an increase in MDA concentration, but they have no influence on DNA. The intensity of AOPP formation depends on the type of factor that it causesfor smelters, occupationally exposure to heavy metals is a stronger oxidation factor than tobacco smoke. The strongest oxidation effect on the protein has $\mathrm{Cu}$ and $\mathrm{Pb}$.

Acknowledgments This work was supported by the grant from Wroclaw Medical University. The authors gratefully thank Professor Jolanta Antonowicz-Juchniewicz from Department of Internal and Occupational Medicine, Wroclaw Medical University, Poland for her support in biological material collection.

Conflict of interest statement The authors declare that they have no conflict of interest.

Statement All persons gave their informed consent prior to their inclusion in the study.

Open Access This article is distributed under the terms of the Creative Commons Attribution License which permits any use, distribution, and reproduction in any medium, provided the original author(s) and the source are credited.

\section{References}

1. Asano H, Horinouchi T, Mai Y, Sawada O, Fujii S, Nishiya T, Minami M, Katayama T, Iwanaga T, Terada K, Miwa S (2012) Nicotine- and tar-free cigarette smoke induces cell damage through 
reactive oxygen species newly generated by PKC-dependent activation of NADPH oxidase. J Pharmacol Sci 118:275-287

2. Valavanidis A, Vlachogianni T, Fiotakis K (2009) Tobacco smoke: involvement of reactive oxygen species and stable free radicals in mechanisms of oxidative damage, carcinogenesis and synergistic effects with other respirable particles. Int J Environ Res Public Health 6:445-462

3. Weiner D, Khankin EV, Levy Y, Reznick AZ (2009) Effects of cigarette smoke borne reactive nitrogen species on salivary $\alpha$-amylase activity and protein modifications. J Physiol Pharmacol 60:127-132

4. Starek A, Podolak I (2009) Carcinogenic effect of tobacco smoke. Rocz Panstw Zakl Hig 60:299-310

5. Yeh C, Barr RG, Powell CA, Mesia-Vela S, Wang Y, Hamade NK, Austin JHM, Santella RM (2008) No effect of cigarette smoking dose on oxidized plasma proteins. Environ Res 106:219-225

6. Klaunig JE, Wang Z, Pu X, Zhou S (2011) Oxidative stress and oxidative damage in chemical carcinogenesis. Toxicol Appl Pharmacol 254:86-99

7. Valavanidis A, Vlahogianni T, Dassenakis M, Scoullos M (2006) Molecular biomarkers of oxidative stress in aquatic organisms in relation to toxic environmental pollutants. Ecotoxicol Environ Saf 64(2):178-189

8. He X, Nie X, Wang Z, Cheng Z, Li K, Li G, Hung Wong M, Liang X, Tsui MT (2011) Assessment of typical pollutants in waterborne by combining active biomonitoring and integrated biomarkers response. Chemosphere 84:1422-1431

9. Zhang XY, Tan YL, Zhou DF, Haile CN, Wu GY, Cao LY, Kosten TA, Kosten TR (2007) Nicotine dependence, symptoms and oxidative stress in male patients with schizophrenia. Neuropsychopharmacology 32 : 2020-2024

10. Delaney S, Jarem DA, Volle CB, Yennie CJ (2012) Chemical and biological consequences of oxidatively damaged guanine in DNA. Free Radic Res 46:420-441

11. Wu LL, Chiou CC, Chang PY, Wu JT (2004) Urinary 8-OHdG: a marker of oxidative stress to DNA and a risk factor for cancer, atherosclerosis and diabetics. Clin Chim Acta 339:1-9

12. Valavanidis A, Vlachogianni T, Fiotakis C (2009) 8-hydroxy-2' deoxyguanosine (8-OHdG): a critical biomarker of oxidative stress and carcinogenesis. J Environ Sci Health C Environ Carcinog Ecotoxicol Rev 27:120-139

13. Pilger A, Rüdiger HW (2006) 8-Hydroxy-2'-deoxyguanosine as a marker of oxidative DNA damage related to occupational and environmental exposures. Int Arch Occup Environ Health 80:1-15

14. Pignatelli B, Li CQ, Boffetta P, Chen Q, Ahrens W, Nyberg F, Mukeria A, Bruske-Hohlfeld I, Fortes C, Constantinescu V, Ischiropoulos H, Ohshima H (2001) Nitrated and oxidized plasma proteins in smokers and lung cancer patients. Cancer Res 61:778-784

15. Zampella G, Neupane KP, De Gioia L, Pecoraro VL (2012) The importance of stereochemically active lone pairs for influencing $\mathrm{Pb}$ II and As III protein binding. Chem Eur J 18:2040-2050

16. Herman DS, Geraldine M, Venkatesh T (2009) Influence of minerals on lead-induced alterations in liver function in rats exposed to longterm lead exposure. J Hazard Mater 166:1410-1414

17. Goyer RA (1993) Lead toxicity: Current concerns. Environ Health Perspect 100:177-187

18. Selmeci L (2011) Advanced oxidation protein products (AOPP): Novel uremic toxins, or components of the non-enzymatic antioxidant system of the plasma proteome? Free Radic Res 45:1115-1125

19. Anraku M, Yamasaki K, Maruyama T, Kragh-Hansen U, Otagiri M (2001) Effect of oxidative stress on the structure and function of human serum albumin. Farm Res 18:632-639

20. Iwao Y, Anraku M, Yamasaki K, Kragh-Hansen U, Kawai K, Maruyama T, Otagiri M (2006) Oxidation of Arg-410 promotes the elimination of human serum albumin. Biochim Biophys Acta 1764:743-749

21. Peng M, Shi S, Zhang Y (2012) The influence of $\mathrm{Cd}^{2+}, \mathrm{Hg}^{2+}$ and $\mathrm{Pb}^{2+}$ on taxifolin binding to bovine serum albumin by spectroscopic methods: With the viewpoint of toxic ions/drug interference. Environ Toxicol Pharmacol 33:327-333

22. Zhang Z, Shuyun S, Liu Y, Chen X, Pen M (2011) Differential effects of $\mathrm{Cu}$ (II) and $\mathrm{Fe}$ (III) on the binding of omeprazole and pantoprazole to bovine serum albumin: Toxic effect of metal ions on drugs. J Farm Biomed Anal 56:1064-1068

23. Liu B, Hou X, Zhou Q, Tian J, Zhu P, Xu J, Hou F, Fu N (2011) Detection of advanced oxidation protein products in patients with chronic kidney disease by a novel monoclonal antibody. Free Radic Res 45:662-671

24. Capeillére-Blandin C, Gausson V, Descamps-Latscha B, WitkoSarsat V (2004) Biochemical and spectrophotometric significance of advanced oxidized protein products. Biochim Biophys Acta 1689: 91-102

25. Selmeci L, Székely M, Soós P, Seres L, Klinga N, Geiger A, Acsády G (2006) Human blood plasma advanced oxidation protein products (AOPP) correlates with fibrinogen levels. Free Radic Res 40:952958

26. Witko-Sarsat V, Friedlander M, Capeillére-Blandin C, Nguyen-Khoa T, Nguyen AT, Zingraff J, Jungers P, Descamps-Latscha B (1996) Advanced oxidation protein products as a novel marker of oxidative stress in uremia. Kidney Int 49:1304-1313

27. Butler AR (1975) The Jaffe reaction. Identification of the coloured species. Clin Chim Acta 59:227-232

28. Bizoń A, Milnerowicz-Nabzdyk E, Zalewska M, Zimmer M, Milnerowicz H (2011) Changes in pro/antioxidant balance in smoking and non-smoking pregnant women with intrauterine growth restriction. Reprod Toxicol 32:360-367

29. Zalewska M, Królik M, Milnerowicz H (2011) Impact of working in metallurgy and cigarettes smoking on the concentration of malonylodialdehyde and 8-hydroksydeoxyguanosine in the blood. Przegl Lek 68:770-774

30. Bouki E, Dimitriadis VK, Kaloyianni M, Dailianis S (2013) Antioxidant and pro-oxidant challenge of tannic acid in mussel hemocytes exposed to cadmium. Mar Environ Res 85:13-20

31. Chatziargyriou V, Dailianis S (2010) The role of selenium-dependent glutathione peroxidase (Se-GPx) against oxidative and genotoxic effects of mercury in haemocytes of mussel Mytilus galloprovincialis (Lmk.). Toxicol In Vitro 24:1363-1372

32. Hanasand M, Omdal R, Norheim KB, Gøransson LG, Brede C, Jonsson G (2012) Improved detection of advanced oxidation protein products in plasma. Clin Chim Acta 413:901-906

33. Bulut M, Selek S, Bez Y, Kayaa MC, Gunesa M, Karababac F, Celikd H, Savase HA (2013) Lipid peroxidation markers in adult attention deficit hyperactivity disorder: new findings for oxidative stress. Psychiatry Res 209:638-642

34. Guo CH, Chen PC, Lin KP, Shih MY, Ko WS (2012) Trace metal imbalance associated with oxidative stress and inflammatory status in anti-hepatitis $\mathrm{C}$ virus antibody positive subjects. Environ Toxicol Pharmacol 33:288-296

35. Hawkins CL, Pattison DI, Davies MJ (2003) Hypochlorite-induced oxidation of amino acids, peptides and proteins. Amino Acids 25: $259-274$

36. Jomova K, Valko M (2011) Advances in metal-induced oxidative stress and human disease. Toxicology 283:65-87

37. Piwowar A, Knapik-Kordecka M, Warwas M (2007) AOPP and its relations with selected markers of oxidative/antioxidative system in type 2 diabetes mellitus. Diabetes Res Clin Pract 77:188-192

38. Witko-Sarsat V, Gausson V, Nguen A, Touam M, Drüeke T, Santangelo F, Descamps-Latscha B (2003) AOPP-induced activation of human neutrophil and monocyte oxidative metabolism: a potential target for $\mathrm{N}$-acetylcysteine treatment in dialysis patients. Kidney Int 64:82-91

39. Kossowska B, Dudka I, Bugla-Płoskońska G, SzymańskaChabowska A, Doroszkiewicz W, Gancarz R, Andrzejak R, Antonowicz-Juchniewicz J (2010) Proteomic analysis of serum of 
workers occupationally exposed to arsenic, cadmium, and lead for biomarker research: a preliminary study. Sci Total Environ 408: 5317-5324

40. Flora SJS, Mittal M, Mehta A (2008) Heavy metal induced oxidative stress and its possible reversal by chelation therapy. Indian J Med Res 128:501-523

41. Antonowicz J, Andrzejak R, Lepetow T, Skoczyńska A, Smolik R (1996) Blood lipid parameters in smelters chronically exposed to heavy metals. Med Pr 47:207-215

42. Bizoń A, Antonowicz-Juchniewicz J, Andrzejak R, Milnerowicz H (2013) The influence of the intensity of smoking and years of work in the metallurgy on pro-oxidant/antioxidant balance in the blood of smelters. Toxicol Ind Health 29:149-161

43. Szkup-Jabłońska M, Karakiewicz B, Grochans E, Jurczak A, NowakStarz G, Rotter I, Prokopowicz A (2012) Effects of blood lead and cadmium levels on the functioning of children with behaviour disorders in the family environment. Ann Agric Environ Med 19:241-246

44. Batáriová A, Spevácková V, Benes B, Cejchanová M, Smíd J, Cerná M (2006) Blood and urine levels of $\mathrm{Pb}, \mathrm{Cd}$ and $\mathrm{Hg}$ in the general population of the Czech Republic and proposed reference values. Int J Hyg Environ Health 209:359-366

45. Madeddu R, Solinas G, Forte G, Bocca B, Asara Y, Tolu P, Delogu LG, Muresu E, Montella A, Castiglia P (2011) Diet and nutrients are contributing factors that influence blood cadmium levels. Nutr Res 31:691-697

46. Hans CP, Chaudhary DP, Bansal DD (2003) Effect of magnesium supplementation on oxidative stress in alloxanic diabetic rats. Magnes Res 16:13-19

47. Lü X, Wang R (2002) Protective effect of magnesium on the damaged cultured endothelial cells induced by oxidized low density lipoprotein. Wei Sheng Yan Jiu 31:244-246

48. Olawoyin R, Oyewole SA, Grayson RL (2012) Potential risk effect from elevated levels of soil heavy metals on human health in the Niger delta. Ecotoxicol Environ Saf 85:120-130

49. Zhang X, Yang L, Li Y, Li H, Wang W, Ye B (2012) Impacts of lead/zinc mining and smelting on the environment and human health in China. Environ Monit Asses 184:2261-2273

50. Żukowska J, Biziuk M (2008) Methodological evaluation of method for dietary heavy metal intake. J Food Sci 73:21-29

51. Dursun N, Dogan P, Donmez H (2001) Plasma and erythrocyte lipid peroxide levels in workers with occupational exposure to lead. Biol Trace Elem Res 82:29-34
52. Turkez H, Geyikoglu F, Tatar A, Keles MS, Kaplan I (2012) The effects of some boron compounds against heavy metal toxicity in human blood. Exp Toxicol Pathol 64:93-101

53. Barbato DL, Tomei G, Tomei F, Sancini A (2010) Traffic air pollution and oxidatively generated DNA damage: can urinary 8-oxo-7,8dihydro-2-deoxiguanosine be considered a good biomarker? A meta-analysis. Biomarkers 15:538-545

54. Garçon G, Leleu B, Marez T, Zerimech F, Haguenoer JM, Furon D, Shirali P (2007) Biomonitoring of the adverse effects induced by the chronic exposure to lead and cadmium on kidney function: Usefulness of alpha-glutathione S-transferase. Sci Total Environ 377:165-172

55. Musarrat J, Arezina-Wilson J, Wani AA (1996) Prognostic and aetiological relevance of 8-hydroxyguanosine in human breast carcinogenesis. Eur J Cancer 32A:1209-1214

56. Çakatay U, Kayali R, Uzun H (2008) Relation of plasma protein oxidation parameters and paraoxonase activity in the ageing population. Clin Exp Med 8:51-57

57. Chirico EN, Martin C, Faës C, Féasson L, Oyono-Enguéllé S, Aufradet E, Dubouchaud H, Francina A, Canet-Soulas E, Thiriet P, Messonnier L, Pialoux V (2012) Exercise training blunts oxidative stress in sickle cell trait carriers. J Appl Physiol 112:1445-1453

58. Selmeci L, Seres L, Antal M, Lukács J, Regöly-Mérei A, Acsády G (2005) Advanced oxidation protein products (AOPP) for monitoring oxidative stress in critically ill patients: a simple, fast and inexpensive automated technique. Clin Chem Lab Med 43:294-297

59. Venturini D, Simão AN, Scripes NA, Bahls LD, Melo PA, Belinetti FM (2012) Evaluation of oxidative stress in overweight subject with or without metabolic syndrome. Obesity 20:2361-2366

60. Dembińska-Kieć A, Drożdż R, Naskalski J (2010) Plasma proteins. In: Dembińska-Kieć A, Naskalski J (eds) Diagnostic Laboratory with the elements of clinical biochemistry, 3rd edn. Elsevier Urban \& Partner, Wrocław, p 200

61. Matteucci E, Giampietro O (2000) Oxidative stress in families of type 1 diabetic patients. Diabetes Care 23:1182-1186

62. Šebeková K, Klenoviscová K, Ferenczová J, Hedwig J, Podracká L, Heidland A (2012) Advanced oxidation protein products and advanced glycation end products in children and adolescents with chronic renal insufficiency. J Ren Nutr 22: $143-148$ 